\title{
Ways of considering traditions when forming the system of maintenance in Ukraine
}

\author{
Olga Petrunia \\ Kyiv National University of Construction and Architecture \\ 31, Povitroflotskyi prosp., Kyiv, Ukraine, 03037 \\ olga petrunya@ukr.netr, orcid.org/0000-0003-3983-4494
}

The manuscript was received on 05.04.2017 and was accepted after revision for publication on 17.10.2017

DOI: $10.26884 / 1707.1803$

\begin{abstract}
The size of the territory, the density of the city dwellers, the number of cars for personal use, planning conditions and network configuration of highways and roads are the main components that influence the placement features of maintenance of motor vehicles in cities of Ukraine.

The article develops the structure of the distribution of cities under types, factors, kinds of functions performed in relation to the economic level and importance of the city as a part of the country; analyzes the impact criteria on the formation of the traditional system of management and living of the people of Ukraine; reveals the traditional approaches to the formation of maintenance in Ukraine.

Keywords: Cities of Ukraine, traditions, crafts and trades, transport and planning structures of the city, motorization level, system of maintenance of motor vehicles for personal use, methods of marketing management.
\end{abstract}

\section{INTRODUCTION}

Ukrainian nation has a rich culture, a huge treasure of which has been formed by valuables and achievements of many generations. Since the ancient times, Ukrainians have accumulated wisdom and guidance on lifestyle. They resulted in the Ukrainian customs, rituals, folklore and life and make the basis for sense of the global consciousness of our people. This

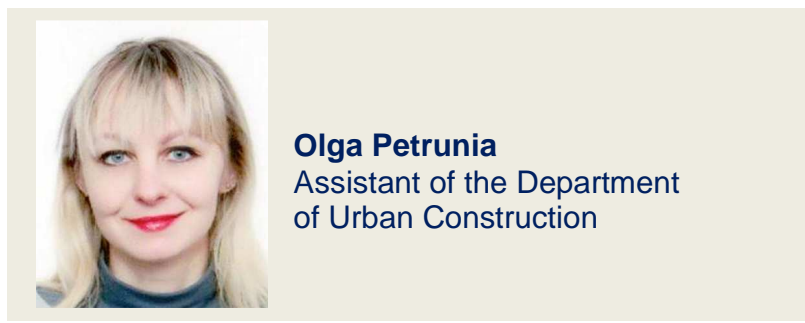

influences the relationship between people, the value of spiritual culture of the individual and the nation in general [1].

Today, the pressing issues include the formation and development of Ukrainian ethnic culture, the discovery of features of the traditional system of management, sustainment by crafts and trades, settlement, housing, transport vehicles and their maintenance.

Each city is a natural and technogenic complex, a component of the landscape area converted by the effort of many generations. It is based on a range of complexes - ramparts, moats, walls, houses, industrial and cultural constructions, reservoirs with dams, bridges, etc. A city is not just the structures with different values put in a natural landscape, but also the peculiar form of coexistence of people, civilization cores, and centers of cultural attraction $[2,3]$. The main task of the urban development is to establish the best conditions for living and welfare of the population improve the transport system, streets and roads 
and localize the points for maintenance of motor vehicles for personal use.

Usually, most cities in Ukraine are small and medium-sized that are located on the territory irregularly. These include centers of administrative districts with different industrial and agro-industrial social facilities. Cities are divided into types depending on the number of population, the size of the area, planning structure, geography, climate and transport infrastructure and the type of functions performed. Their ratio determines the level of the economic role of city in the region or the country in general [4].

From the period of establishing cities up to currently, we can trace close ties between a number of complex components.

Customs are those unwritten laws that govern daily and the largest all-national affairs, such as the language; they were formed and perfected throughout life and development of every nation. Each former historic period in the life of society brings scientific achievement for the next generation. The method of trial and error leads to results, new ideas and opportunities, refines certain elements. Care about the next generations requires forecasting and thinking what can occur in the environment and with what consequences.

\section{PURPOSE AND METHODS}

The aim of the article is to identify the main criteria of influence on the global consciousness and the existing system of maintenance of motor vehicles for personal use in Ukraine; having analyzed the historical periods of its development, traditions, development stages up to the present times, to describe the existing system of maintenance of motor vehicles for personal use; highlight the issues and trends in the development of this system in future.

Tradition (lat. - transfer) - elements of social and cultural heritage that are conveyed to future generations and preserved for a long time by the society as a whole or in separate groups. It appears as appointed, stereotyped behavior, customs, rituals, social ideas, moral and ethnic elements, etc. [5].
The search and researches conducted helped find out the following criteria on forming the influence of the traditional system of management and sustainment of the population in ci-ties of Ukraine:

1) functions of the city:

- number of residents;

- Genesis (what nation has founded the city and when);

- place in the settlement system (an agglomeration center, a satellite city, a local center, a recreational, scientific or industrial center, a transit point)

- occupations of residents (mostly unrelated to agriculture);

- type of construction of the territory;

- development of villages; traditions;

- density of the population; versatility of trades;

- existence of a market as a constant commodity exchange at the settlement (commodity character of production activities) $[2,6]$.

The main tasks of planning and urban development are, as follows: to justify future needs and determine the preferred areas for the use of the territories; take into account the state, public and private interests during planning, construction and other use of the territories; justify the division of lands for the intended purpose and the use of the territories for urban needs [7].

Function of the city determines its role in society. The main activities of city dwellers cause the following features: city-forming (exogenous) and city-servicing (endogenous).

2) Economic and geographical (transport and geographical) location of the city is one of the main factors of the formation of the city on the territory; it affects the development of production and the creation of inter-territory relations of different scale:

- industrial and geographical location depending on the source of energy, raw materials (wood, metal), processing industry;

- agro-geographical - location depending on the production bases and agricultural raw materials;

- transport and geographical - location depending on sea and main-line tracks, transport hubs; 
- sales and geographical - location depending on markets for sale of capital goods (coal, ferrous metals), markets for consumer goods;

- demo-geographic - location depending on human resources, scientific and technical personnel. Production and territorial relations are important, in terms of freight traffic flows - a location foreign economic relations; concerning passenger traffic - mostly domestic transportations $[2,8]$.

3) number of residents.

In Ukraine, according to statistics as of January 2013, there are about 450 cities. According to DBN/State Construction Coe 360$92 *$ depending on the number of population, cities of Ukraine are divided into the following groups:

- the most significant (larger) - the population is over 1 million people (Kyiv, Kharkiv, Odessa);

- significant (large) - the population is 1 million - 500 thousand (Dnipro, Donetsk, Zaporizhzhia, Lviv, Kryvyi Rig). Cities in this group are the centers of industry, transport and service sector;

- big - 14 cities with the population of 500250 thousand people and 22 cities with the population of 250 - 100 thousand people;

- average - 47 cities with the population of 100-50 thousand people;

- small - 341 cities with the population less than 50 thousand people [9-11].

The functional structure of the city actively influences the number of its inhabitants. Multifunctional cities are more densely populated with faster growth rates in the population. This affects the age and professional composition of the dwellers, their living standards.

National peculiarities of beauty perceptions are closely related to the specific local conditions that are clearly seen on the architecture. Traditional housing in different regions is mostly adapted to climatic and environmental conditions and activities of the inhabitants. Traditions of constructing a dwelling were conveyed from generation to generation, buildings were aesthetic zed; people got accustomed to their home, it was the most beautiful to them. Even later, when the assortment of building materials increased, when clay and wood were replaced by brick, the construction of buildings continued preserving the previous forms, as they were considered natural, they comply with local tastes and determined the style of a particular area. Artistic features initially merged with national, traditional, folk and ethnic ones and became the signs of ethnicity.

Along with the changing lifestyles, our ancestors were acquiring more and more knowledge. It laid the basis for the global consciousness as the system of view points concerning the world and the place of man in it, the relations of human with the surrounding nature and science, changing scientific approaches $[12,15]$. For several thousand years, man has developed since the invention of the wheel to the exploration of the universe. The role of transport in the life of the planet, state and city is really important because only movement leads to progress.

The analysis of the history of transportation maintenance and repair of vehicles in Ukraine enables to identify and study periods of formation and establishment of the industry.

The beginning of change in the outlook on the importance of a car is considered to be 15 May 1910, when the International Automobile Exhibition was opened in Kyiv, aimed at "Drawing attention of everyone who has doubts and prove that a car has been already in our lives and there no distances for it" [13, 14].

In the first stage, the need for cars was met due to their imports from abroad. Later, because of the necessity to decide first of all more important national economic and defense problems in the pre-war and post-war years, lorries were preferred. The critical stage of the development transport is considered to be 1929, when it was decided in Russia to construct two large plants in Moscow and Gorkyi.

In 1927 - 1930 years, special garages were organized in Kharkiv, Kyiv, Dnipropetrovsk and Zaporizhzhia. It was time for preventive maintenance of vehicles. Since 1932, the mass production of domestic cars has started. In the post-war years, the automotive industry has increased considerably. There automobile factories and enterprises appeared. 


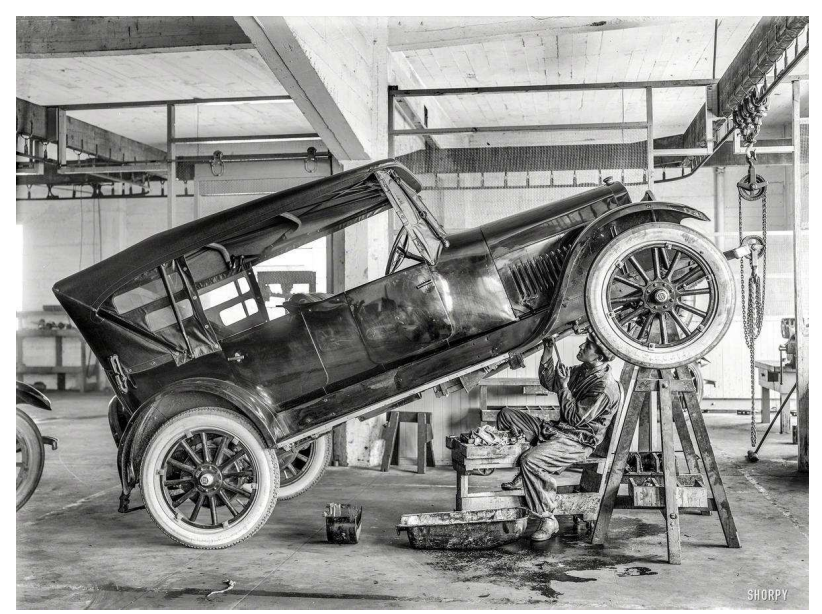

Fig.1. Example Car maintenance station in 1932

Until 1959 in Ukraine, there were no avtomobile plant. Therefore, its fleet was formed as a result of the acquisition of cars for import and manufacturing plants built in Russia and other republics of the former Soviet Union (Fig.1).

In 1975, the Main Information Center was formed, the chief directorate of "Ukrglavavtotehobsluzhyvanie"/the Ukrainian Main Automobile Maintenance was reorganized into an independent Respublic Industrial Association "Ukrglavavtotehobslugovuvannia"/the Ukrainian Main Automobile Maintenance.

In 1984, a new industry began functioning on the territory of the CIS - automotive maintenance (Fig.2). Its creation was caused by a high growth of the vehicle fleet. At the same time, we can observe the acceleration of technological progress, technical reequipment and reconstruction of existing production through improving the design of vehicles, consolidation of logistics of automobile enterprises and due to better road conditions.

In 2000 the State Department on Road Transport was established (within the Ministry of Transport and Communication of Ukraine), which is the administrative body of state management in road transport and operates within the transport infrastructure. "Ukravtotrans" performs respectively the following tasks and functions: provides in accordance with the law the state regulation in automobile transport and exercises control over the adherence by

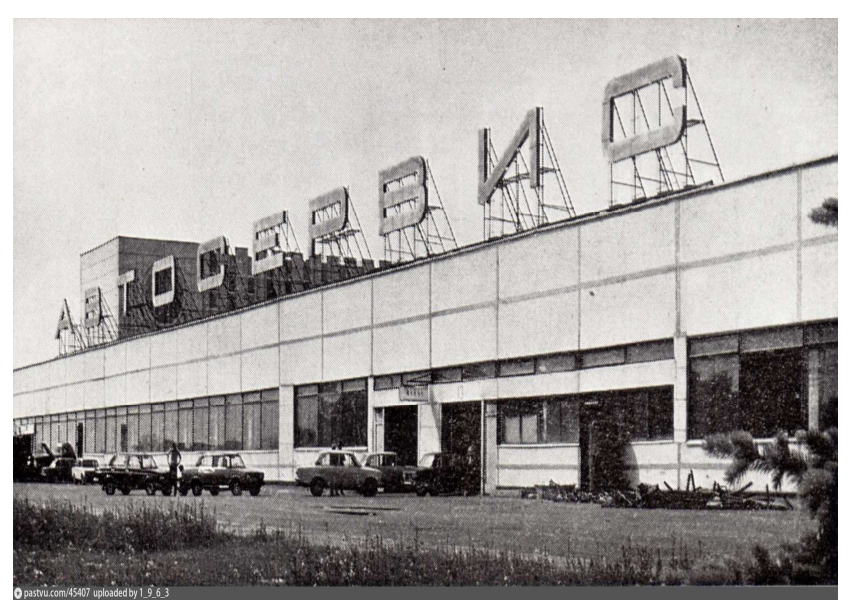

Fig.2. The facade of the station servicing tires car 25 work stations in 1987

Ukrainian and foreign transportation organizations to Ukrainian transport law, rules of passenger and freight transportation, etc., regulations governing the functioning of motor vehicles. It promotes within its area of competence the reduction of harmful effects of road transport on the environment and the implementation of energy saving activities [13, 16].

In 2016, there was a significant increase of cars in Ukraine due to our own production companies: Zaporizhzhia Automobile Plant CJSC - produces motor vehicles: Opel, Daewoo, Chevrolet, Tavria, Slavuta and their lorries: TATA, Dong Fend; Lutsk Automobile Plant, OJSC - VAZ, Izh, KIA, Hyndai; Eurocar CJSC - Skoda, VW, Audi; UkrAVTO corporation (ZAO “ZAZ”) [13, 17].

There is considerable competition and oversupply of the market for the sale of vehicles (Fig.3).

\section{RESULTS}

The main condition for the successful functioning of any enterprise is the correct marketing management. It enables to predict the future state of the enterprise and the environment, in which it exists; to identify the possible changes and weaknesses in the supply management system in all spheres, based on the predicted activities of the enterprise on the maintenance of motor vehicles for personal use. 


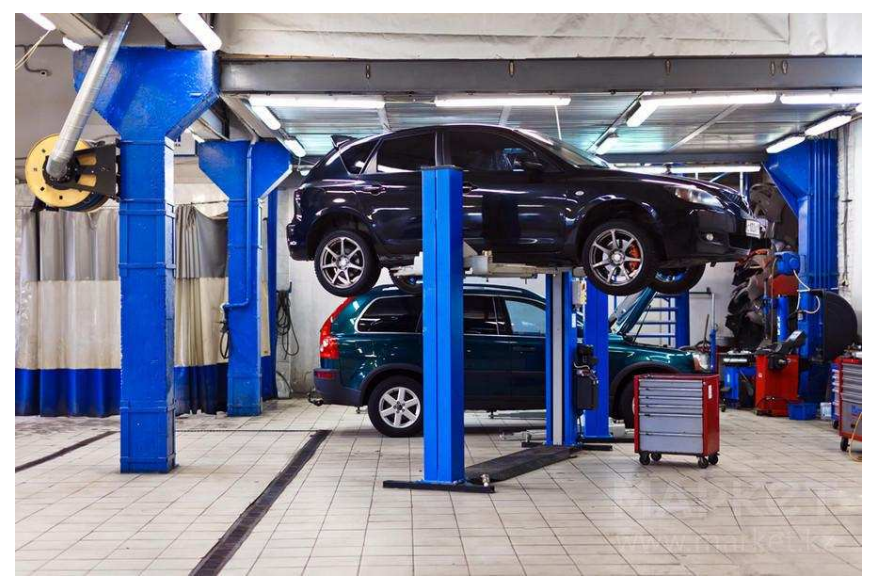

Fig.3. Example serviced individual use of cars at the station in 2017

Due to the estimates of predicting sales, lifecycle and profit potential of a particular segment or product market, we can perform a full analysis of the attractiveness of the market (Fig.4). This approach is important for making decisions on the volume of investments in construction of such facilities in future and their production capacity [18].

To this end, we use different methods of prognosis. Based on inductive and deductive approaches, methods of prognosis can be simple and complex $[19,20]$. There are:

1) factual - based on facts, information materials on former and current development of the object of prognosis;

2) expert (intuitive) - based on an expert opinion about the object prediction and gener-

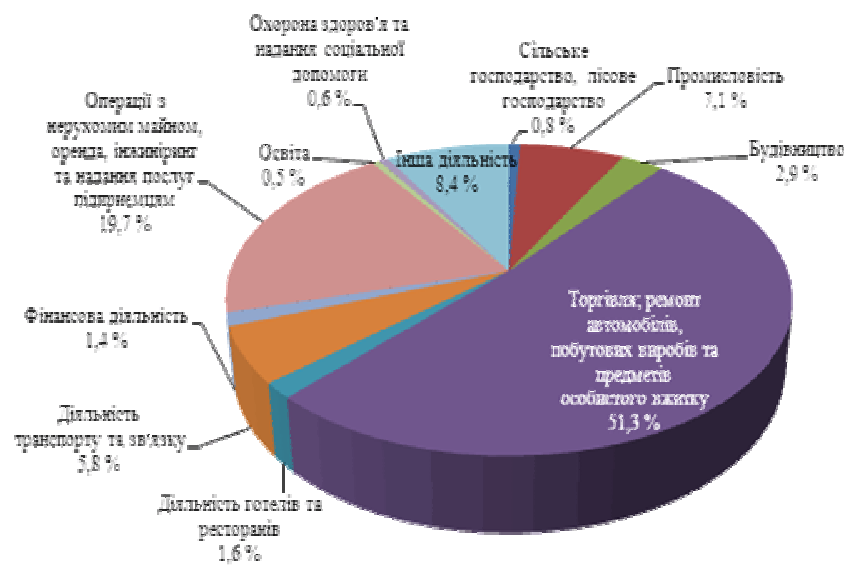

Fig.4. The distribution of economic Business of private enterprises in Ukraine in 2017 alization of their conclusions on its development in the future;

3) combined - include methods with mixed information basis, when factual data is used as initial together with expert opinions.

To account possible changes and improvements in results and efficiency of activities of the enterprise, one can use statistical methods. The static analysis includes the process of assessing the quality of products and raw materials, the composition of components and tools; estimates of changes in production and technological processes due to statistical management (control cards, management cards). The result is determined by the composition of the original data, their volume, the registration order, storage and verification of the validity; the analysis of data; developed and documented recommendations on the results of data [21].

The method of expert evaluations is rather well-known as well, when experts conduct intuitive and logical analysis of the problem with the quantitative assessment of problems and formal treatment of results. The result gained (the summarized expert opinion) is treated as the solution to the problem. During the process of management, experts form objects (alternative situation, goals, solutions, etc) and carry out measuring of their characteristics (probability of an event, rate of importance of the purpose) [22].

Based of the material provided, we can conclude that in $2017-2018$ years the number of motor vehicles for personal use in the cities of Ukraine will increase. The annual trend of growth in certain brands of cars is associated with the needs to use these types of facilities. This automatically affects the necessity for their maintenance. There is a directly proportional relation between the size of the city, its population, the level of car ownership and the availability of facilities for servicing [23].

Thus, due to significant changes in the inner transport environment of the city, there is a problem in prognosis of service centers for motor vehicles.

As for some time Ukraine was a part of Russia and had no independent automotive 


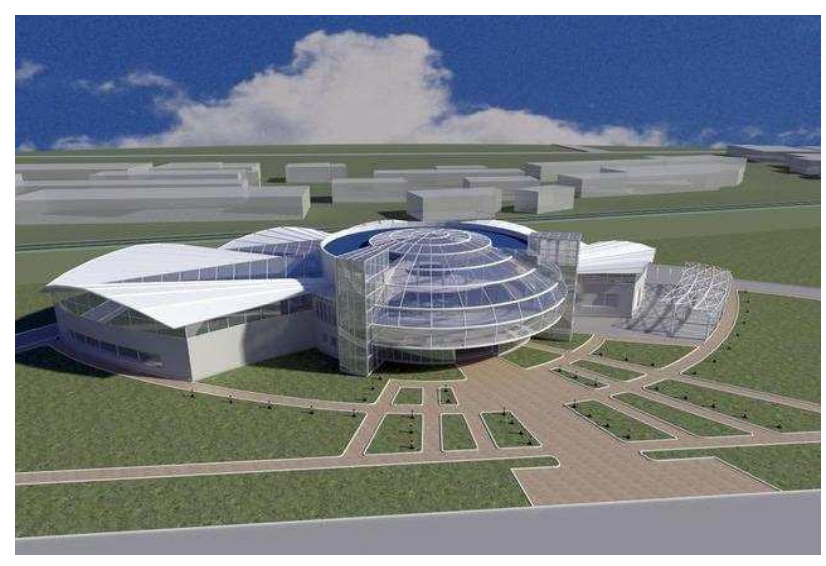

Fig.5. Example design visualization service stations for passenger cars. A look at the future

manufacturing and the car park was formed due to the acquisition of vehicles via imports, even now we use both domestic and foreign brands.

Traditional approaches to designing and construction of maintenance facilities in Ukraine should be aimed at improving the economy (Fig.5). In order to gain fast profit and return investment put in the project, it is advisable to use standardized structural elements and tested materials, improve software and hardware and technologies (Fig.6).

\section{CONCLUSIONS}

1. The main tasks of planning and urban development are: to justify future needs and determine the preferred areas for the use of the territories; take into account the state, public and private interests during planning, construction and other use of the territories; justify the division of lands for the intended purpose and the use of the territories for urban needs.

2. We have analyzed historical periods of the automotive industry. Enterprises of road transport are relatively new types of structures, the occurrence of which is associated with the rapid development of the car park, freight and passenger transport. Change of market potential of services for motor vehicles depends on time and external factors: the traditional approach, habits, cultural values, income, technology, prices, legislation, etc.

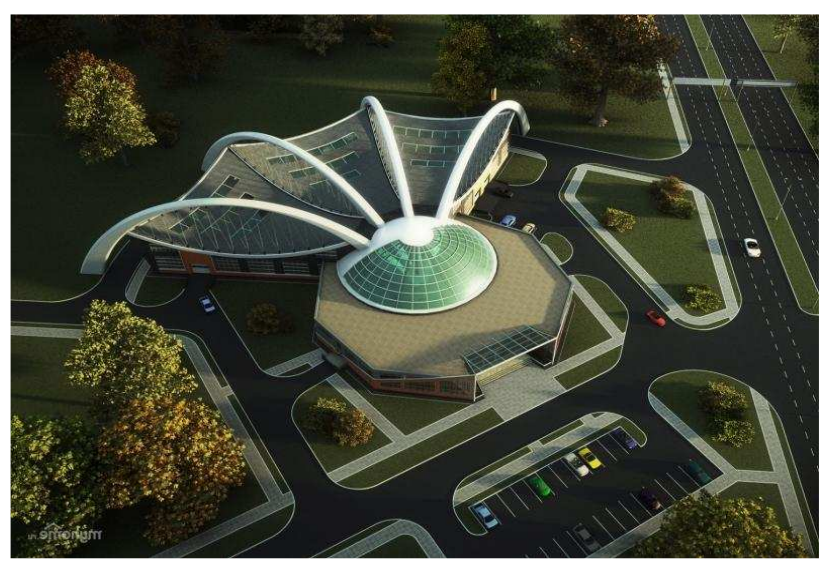

Fig.6. Example draft unified stations for cars individual use. A look at the future

3. We have provided methods of marketing management for the successful operation of the company for maintenance of motor vehicles for personal use.

\section{REFERENCES}

1. Bilan M.S., Stelmashchuk G.G., 2000. Ukrainian formation: Manual for higher and secondary educational establishments G.G., Institute of Ethnography of the National Academy of Sciences of Ukraine. Lviv Academy of Arts, Research Center, Lviv, Phoenix, 328.

2. Rishard B., 2001. City: Definition and Functions. Economic Journal, XXI, Nr.9, 25-29.

3. Sergiy Polovko, 2015. Historical cut of geological study of Azov Black Sea by the researchers of Ukraine. Underwater Technologies, Vol.02, 11-23.

4. Mocherny S.V., 2001. Economic Encyclopedia. Kyiv, Academy, Vol.2, 848.

5. Pavliuk H.Y., 1994. Ukrainian Ethnology: Manual. Lviv, Phoenix, 608.

6. Baranov A.V., 1981. Social and Demographic Development of a Big City, Moscow, Science, 184.

7. Osietrin M.M., Petrunia O.M., 2003. Analysis of Placing and Operating Principles of Points for Maintenance in Kyiv (based on Solomianskyi District). Urban and territorial planning, Scientific and technical collection, Kyiv, KNUBA, Nr.19, 263.

8. Matiash S., 1990. Man in the City: Sociologist. Essays, Kyiv, Politizdat of Ukraine, 223.

9. http://www.ukrcensus.gov.ua. 
10.DBN 360-92*, 1993. Urban Construction, Planning and Development of Urban and Rural Settlements. Kyiv, Ukrarhibudinform, 107.

11.Boriak A.A., 2006. Ukraine: Ethnic and Cultural Mosaic. Kyiv, Lybid, 328.

12.Skrypnyk G., 2005. Ukrainians. Historical and Ethnographic Monograph. In 3 Volumes, Vol.02, Kyiv, IMFE, 256.

13.Petrunia O.M., 2007. Development of motorization and the system of maintenance of motor vehicles in Ukraine. Urban and Territorial Planning. Scientific and technical collection, Kyiv, KNUBA, Nr.27, 388.

14.Yudin V.A., Samoilov D.S., 1975. Urban Transport. Moskow, Strojizdat, 287.

15.Sigaev A., 1972. Motor Transport and Urban Planning. Moskow, Strojizdat, 22.

16.Petrunia O.M., 2013. Influence of Planning and Transport City Structures on the Formation of the System of Maintenance of Motor Vehicles for Personal Use. Urban and Territorial Planning, Scientific and technical collection, Kyiv, KNUBiA, Nr.50, 824.

17.Markov A.D., 1998. Organization of Motor Service. Leningrad, Oriana nova, 529.

18.Jean-Jacques Lambe, 1996. Strategic Marketing. European Prospects, Translation from French, Sankt-Petersburg, Science, XV, 589.

19.Mykola Osetrin, Oleksiy Dvorko, 2016. Environmental criteria in a model assessment of the effectiveness of simple intersections on the road network of Kyiv. Underwater Technologies. Vol.04, 80-89.

20.Aniskin Yu.P., 1994. Planning inside the Company: Manual. Moskow, MGIET, TU, 456.

21.AO NITS KD SMTS. 2001. Statistical Management of Processes. SPC, Translation from English, Novgorod Priority, ed. 4th, 181.

22.Beshelev S.D., Gurvich F.G., 1976. Expert Opinions in Making Planned Decisions. Moskow, Economics, 287.

23.Mykola Osetrin, Oleksandra. Bondar, 2016. The town planning experience in implementing the principle of roundabouts on the approaches to bridges. Underwater technologies. Vol.03, 75-82.

\section{Способы использования традиций при формировании системы технического обслуживания в Украине}

\section{Ольга Петруня}

Аннотация. Размер территории, расчетная численность населения города, количество автомобилей индивидуального пользования, планировочные условия, конфигурация сети магистральных улиц и дорог - основные составляющие, которые имеют влияние на особенности размещения системы технического обслуживания легковых автомобилей в городах Украины.

Разработана структура распределения городов по типам, факторам, видам выполняемых функций в соотношении с экономическим уровнем та значением города в составе страны. Проанализированы критерии влияния на формирование традиционной системы ведения хозяйства и жизнедеятельности населения Украины. Выявлены традиционные подходы к формированию системы технического обслуживания в Украине.

Ключевые слова: города Украины, традиции, народные промыслы и ремесла, транспортная и планировочная структуры города, уровень автомобилизации, система технического обслуживания легковых автомобилей индивидуального пользования, методы маркетингового управления. 